\title{
HIP MONOARTHRITIS AS HODGKIN'S LYMPHOMA INITIAL MANIFESTATION: CASE REPORT
}

Fabiana de Castro Machado (UFMT, Sinop, MT, Brasil), Gabriel Freitas de Campos (UFMT, Sinop, MT, Brasil), Andressa Gabrielly Rodrigues Beserra (UFMT, Sinop, MT, Brasil), Diogo Rios de Avila (UFMT, Sinop, MT, Brasil), Allana Campos Alves (UFMT, Sinop, MT, Brasil), Gabriel Ribeiro Leão Barroso (UFMT, Sinop, MT, Brasil), Heloisa Maria Lopes Scarinci (UFMT, Sinop, MT, Brasil), Flavio Fernandes Barboza (UFMT, Sinop, MT, Brasil)

\section{BACKGROUND}

Hodgkin's lymphoma $(\mathrm{HL})$ is a neoplasm of the lymphatic system characterized by the presence of Hodgkin and Reed-Sternberg cells. The most common clinical manifestations of this comorbidity are fever, night sweats and weight loss, as well as adenomegalies of firm and painless consistency. Other symptoms are related to the area affected by the neoplasm, mainly the cervical and axillary lymph nodes. It is observed, therefore, that the initial osteoarticular manifestation is rare, with incidence of less than $2 \%$ of cases.

\section{CASE REPORT}

A 31-year-old man presented with migratory polyarthralgias that settled in the right hip, manifesting with pain and lameness, associated with dry cough, weight loss, fever and night sweats. Laboratory tests showed hemoglobin $(\mathrm{Hb})=12.8 \mathrm{~g} / \mathrm{dL}$; leukocytes $=11,340 \mathrm{~mm}^{3}$; lymphocytes $=1,168 \mathrm{~mm}^{3} ;$ platelets = $498,000 \mathrm{~mm}^{3}$; fibrinogen $=575 \mathrm{mg} / \mathrm{dl}$; albumin $=3.3 \mathrm{~g} / \mathrm{dL}$; erythrocyte sedimentation rate $(\mathrm{ESR})=70 \mathrm{~mm}$; and $\mathrm{C}$-reactive protein $(\mathrm{CRP})=80$. Further investigation revealed hilar bilateral lung infiltrates(figure1), and, because of the presented picture, a sputum examination was performed. We then performed a biopsy of the lesion, which returned nonspecific. As the lung biopsy was negative, a hip resonance was requested to investigate the osteoarticular condition, evidencing an extensive and infiltrative lesion of the right iliac and invasion of the right hip(figure2). The biopsy was compatible with HL, later staged with PET$\mathrm{CT}$, establishing lung lesions as invasion by Hodgkin's disease. The patient was referred to the hematology service to start chemotherapy.

\section{CONCLUSION}

It is known that the presence of osteoarticular manifestations in lymphomas is atypical. However, it is extremely important that the rheumatologist is aware of intense joint manifestations associated with systemic signs in young people. They may indicate the presence of a subjacent neoplasm. 